\title{
SEX ROLE STEREOTYPING AND ART EDUCATION
}

\section{Alana Stelker-Horner}

"I am a parent, an artist, a student and a teacher."

When I was a child, I was told, "When you come right down to it, art is not important." Later, when I went to art school I learned that large works, large blocks of time, and a space separate from my daily life were imperative if I wanted to be an artist. When I married and had children I searched for those blocks of time that seldom could happen, and the separate space that was never possible.

\section{I stopped painting.}

When we sent our son to school for the first time, he was roughed up for hugging and kissing a new-found friend. When we sent our daughter to school she was excluded from her group for her "tomboyish" behaviour. And when in school they took art which their parents had taught them to value they were told, when you come right down to it, "Art is not important."

Available research has shown, that boys are superior in logical thinking, that they are less afraid of failure, less conforming and that female thinking is less analytic, more global and more preservative, but the stereotypical male like the stereotypical female is not creative. While independence is considered to be a masculine characteristic, sensitivity is considered to be feminine. Many studies now show that the creative individual combines masculine and feminine qualities and that highly sex-typed persons, i.e. masculine boys and feminine girls are low in 1Q, in spatial ability and creativity. We may say then, that the creative individual is open to wideranging experiences and resists pressure to be limited and conform to his or her stereotype.

In her paper on sex-role stereotyping in children's art, Sylvia Feinberg (Loeb, 1979) found that children's drawings revealed their social perceptions. Feinberg discovered that children of five and six, when given free choice, chose themes that reveal substantial differences between the sexes. She found that girls' subjects are "interpersonal" - friends, parents, and children, while boys' subjects are "depersonal" - objects, devices, vehicles and mechanical equipment. This should not seem surprising since as early as three years of age children have internalized what is distinctly "male" or "female" behaviour. Boys are given approval for energy, activity, and exploration; girls are given approval for pursuing activities of a more personal nature. As a result, socialization polarizes boys and girls into separate, equally destructive worlds where the boy will learn subordination of self and the girl will struggle with her loss of credibility, because we value one set of gender characteristics over another. This polarization will also ensure that art as a "useless" product will continue to be little respected in this society.

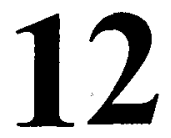


The ability to function within the personal and depersonal is important for all regardless of sex. Girls would benefit from goal-oriented, groupdirected behaviour as seen in a more depersonalized context, but boys also would benefit from functioning more sensitively on the interpersonal level.

Reform for non-sexist art education has by-passed school-age children in focussing on artist-oriented education. Educators have concentrated their efforts in sex-role stereotyping on subjects such as math, social studies, language arts etc. There has been little effort made to discover what role art education might play in dealing with sexist influences in education or how to provide an alternative to sexist education. Through an involvement in consciousness-raising, resulting changes in art education could provide children with the freedom to make choices not based on gender, and help them to move toward a world in which individual roles can be freely chosen. Liberated from the confines of polarization, art education would involve the incorporation of male and female principles, both being of equal value. If male characteristics are transcendent and female characteristics emmanent, these characteristics are equally important to creativity. Because art education lays emphasis on the art experience as a form of transcendence, we must develop experimental programs that will question that bias.

Sarah Sternglanz (1974), in researching sex-role stereotyping found that when teachers reward young girls for playing with each other with attention and praise, "cross-sex play" increased and toys became unisex. When such play was ignored and "same-sex play" received the teachers' attention, "The boys went back to their trucks and the girls to their kitchens." From this sample of a possible teaching method which works at finding a solution to sex-role stereotyping, we see that structures can be devised.

The need to find and apply teaching methods designed to do away with sex-role stereotyping is urgent. If, as research seems to suggest, the truly creative person resists pressure to be limited and conform to the sex-role stereotype, by allowing boys and girls to constantly reinforce their gender roles we as art educators may be helping to ensure that creative expression will not grow and develop in our children.

\section{REFERENCES}

Bardwick, Judith in Edurating Women in the Visual Arts Judy Loeb ed. Teachers College Press, 1979.

Nagel, Cindy. "Psychological Androgyny - An Exploration" in C.anadian Women's Studies, Vol. 3, No. 2, 1982, p. 51.

Feinberg, Sylvia Gruber, "The Significance of What Boys and Girls Chose to Draw" in Judy Loeb ed. Feminist Collage: Educating Women in the

Visual Arts. N.Y. Teacher's College Press, Columbia University, 1979, p. 185.

Collins, Georgia. "Feminist Approaches to Art Education" in Journal of Aesthetic Education. Vol. 15, No. 2, 1981, p. 83.

Sternglanz, Sarah and Serbin, Lisa . "Sex Role Stereotyping in Children's Television Programs". Developmental Psychology Vol. 10, 1974, p. 710-715. 